\title{
Reproductive Biology of Oci Fish Selaroides leptolepis in Tomini Bay
}

\author{
Nuralim Pasisingi ${ }^{1 *}$, Putri Sapira Ibrahim², Zulkifli Arsalam Moo¹, Munirah Tuli ${ }^{1}$ \\ ${ }^{1}$ Department of Aquatic Resources Management, Faculty of Fisheries and Marine Sciences, \\ Universitas Negeri Gorontalo \\ ${ }^{2}$ Oceanographic Research Center, Indonesian Institute of Sciences \\ ${ }^{*}$ Corresponding author, e-mail: nuralim@ung.ac.id
}

\begin{abstract}
Local people name Selaroides leptolepis distributed in Tomini Bay as Oci Fish. A study of the fish reproductive biology, which is one aspect of fisheries biology, is crucial to support the implementation of sustainable Oci Fish resource management policies. This study aims to determine the average length at first maturity, gonad maturity stages, and fecundity of the fish in Tomini Bay. Sampling was carried out using a stratified random sampling method from the catches of the fishermen landed in Fish Landing Base Kampung Tenda, Gorontalo City. The time interval sampling was conducted per month during April, May, and June 2020. Fish and egg samples preserved using ice cubes and a 10\% formaldehyde solution correspondingly. The results of the study showed that the Oci Fish in Tomini Bay had a length range of the first maturity between 166 and $174 \mathrm{~mm}$ with a gonad maturity index ranging from 1.773 to $2.760 \%$. The average fish fecundity was $16623 \pm 4850$ eggs.
\end{abstract}

Keywords: fisheries biology, gonadosomatic index, Selaroides leptolepis, Tomini

\section{INTRODUCTION}

The semi-enclosed area makes Tomini Bay as the nutrient-rich waters supporting aquatic organism life. Tomini Bay functions as a spawning, nurturing, and catching area for numerous types of fishery resources (Wagiyo et al., 2019). Administratively, the bay is located in the south of the Gorontalo Area. Therefore, Gorontalo fishers depend on the catch from the bay (Nento et al., 2014; Mardijah \& Rahmat, 2016; Asruddin \& Hasan, 2019; Adam et al., 2020). Tomini Bay is part of the territory of the Republic of Indonesia Fisheries Management/Wilayah Pengelolaan Perikanan Negara Republik Indonesia (WPPNRI) 715 (Rahmat \& Witdiarso, 2017). Suwarso et al. (2017) mentioned that fish resources in this region are open access and likely to be shared stocks with several countries.

Oci, as one of the Tomini Bay fish resources, is a local terminology used by the Gorontalo community to a fish that is relatively little in shape with elongated flat bodies, has small scales, and a yellowish color from anterior to posterior alongside the body. In several publications, Oci is known as Selar fish (Baskoro et al., 2020; Imbir et al., 2019; Sahara et al., 2020). The small pelagic fish that has the scientific name as Selaroides leptolepis is also named as the yellowstrip scad. (Fawzya et al., 2020; Fuad et al., 2020; Hussin et al., 2019; Jaafar et al., 2020; Desrita et al., 2020). Oci is categorized as an essential commodity for local society due to its high market demand. Gorontalo fishermen informed that the price of the fish is ranging from 15,000 to 30,000 IDR per $\mathrm{kg}$.

Not only has an economic value, but Oci fish also plays a role in the aquatic ecosystem balance. Oci fish eats phytoplankton, zooplankton, and small crustaceans (Sriyati et al., 2018), and in the next trophic level, the fish fall prey to other predators. S. leptolepis are a group of carnivorous fish which can be seen from the Prefonderance Index value which consumes Copepoda (Anugerah et al., 2019)

Hatta \& Mulyani (2019) stated that excessive low-level trophic fishing could be detrimental as it may reduce the carrying capacity of large pelagic fish with higher economic value. Gorontalo fishers conduct Oci fishing in Tomini Bay to fulfill the market demand. Ecologically, resource exploitation without considering aspects of sustainability and conservation will threaten the sustainability of the fish in nature. If there are inappropriate management measures implemented, 
the worst possibility that would occur in the future is the decrease of catches. Conversely, the fishing under an optimal condition would bring the potential to support the implementation of a strategy to improve the welfare of fishing communities. Nationally, the potential of small pelagic fish has not been used optimally. However, in other waters, the resources were overexploited (Khatami et al., 2019).

The potential of fisheries in the Tomini Bay region can contribute to regional development and community welfare if managed in an integrated and sustainable way based on data and comprehensive scientific studies. Previous studies of aspects of Oci fishing and other small pelagic fish in Tomini Bay have been carried out (Rahmat \& Witdiarso, 2017; Asruddin et al., 2019; Madjowa et al., 2020). However, reproductive biology information has not been available. Reproductive biology study is one aspect of fisheries biology needed by stakeholders to support the application of sustainable fish resources management policies. This study aims to determine the gonadal maturity stages (GMS), the size of the first gonad mature fish, gonadosomatic index (GSI), and the fecundity of Oci S. leptolepis in Tomini Bay.

\section{MATERIALS AND METHODS}

Sampling was done through collecting Oci fish landed at the Fish Landing Base (PPI) Kampung Tenda, Gorontalo City, by fishermen who do fishing in the Tomini Bay area (Figure 1). Fish samples were taken using a stratified random sampling method from the fishermen catch landed at the PPI. Sampling time intervals were per month during April, May, and June 2020. Fish samples and the eggs were preserved with ice cubes. Samples were analyzed in the Laboratory of Fisheries and Marine Science, Gorontalo State University.

The total length and the weight of samples were measured using a ruler and a digital scale, respectively. Furthermore, determining the sex and maturity level of the gonads was performed visually after the sample was dissected. Gonads were weighed using a digital scale (accuracy = 0.001 gram) prior to preserving samples in a $10 \%$ formaldehyde solution. A magnifying glass was used to provide a more accurate calculation of fecundity.
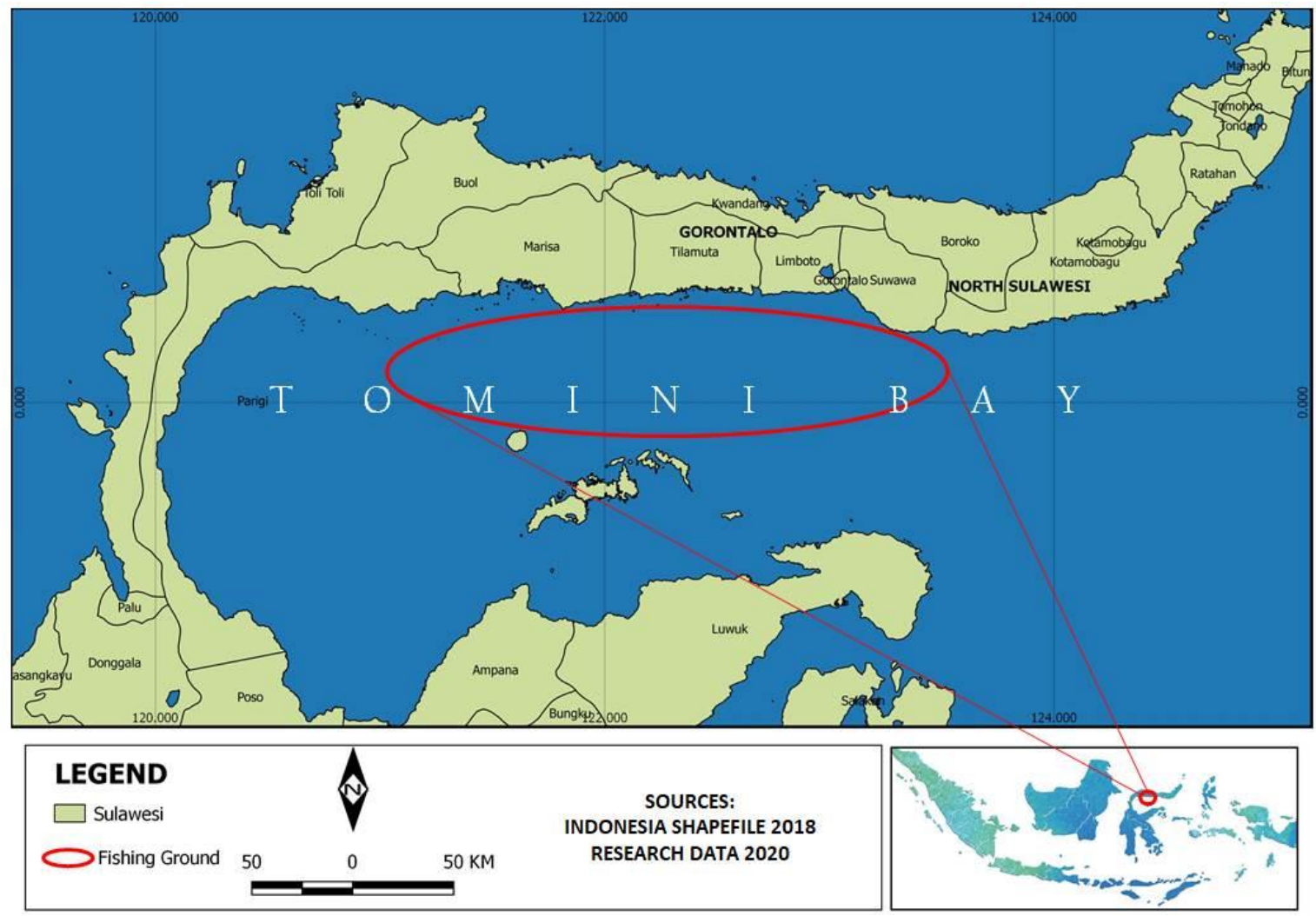

Figure 1. Oci Selaroides leptolepis fishing ground by Gorontalo fishers in Tomini Bay 
The data obtained include the total length and weight of fish, sex, gonadal maturity stages, gonad weight, and the number of eggs. Data were analyzed descriptively for providing information on gonadal maturity stages, the size at first gonad maturity, the gonadosomatic Index, and fecundity of the fish.

\section{Gonadal Maturity Stages (GMS)}

Analysis of Gonad Maturity Stages (GMS) of fish refers to modification method by Cassie (1954) in Effendie (1997) with the detail description in Table 1 below:

Tabel 1. Determination of Fish Stages of Gonadal Development (Cassie 1954 in Effendie 1997)

\begin{tabular}{|c|c|c|}
\hline GMS & Female & Male \\
\hline Stage I & $\begin{array}{l}\text { The ovary is like a thread, extending } \\
\text { to the front of the body, smooth } \\
\text { surface }\end{array}$ & $\begin{array}{l}\text { Testes are threadlike, apparent in color, and } \\
\text { the edges are visible in the body cavity }\end{array}$ \\
\hline Stage II & $\begin{array}{l}\text { Larger ovaries, yellowish in color, and } \\
\text { the eggs are not yet clearly visible }\end{array}$ & Larger testes, milk-colored \\
\hline Stage III & $\begin{array}{l}\text { Ovaries are yellow; morphologically } \\
\text { the eggs begin to appear }\end{array}$ & $\begin{array}{l}\text { The surface of the testes appears jagged, the } \\
\text { color is whiter than the previous level, and the } \\
\text { size is getting bigger. }\end{array}$ \\
\hline Stage IV & $\begin{array}{l}\text { Ovaries are getting bigger; the eggs } \\
\text { are yellow, easily separated. Oil grain } \\
\text { is not visible, filling the body cavity of } \\
1 / 2 \text { to } 2 / 3\end{array}$ & $\begin{array}{l}\text { The testes easily broken in preserved } \\
\text { conditions and increasingly solid }\end{array}$ \\
\hline Stage V & $\begin{array}{l}\text { Crimped ovaries, thick walls, leftover } \\
\text { eggs near the release area }\end{array}$ & $\begin{array}{l}\text { The back of the testes is deflated while in the } \\
\text { near release area it still contains }\end{array}$ \\
\hline
\end{tabular}

\section{Mean size at first maturity in the population.}

Length at first maturity gonad $(\mathrm{m})$ was predicted using the Spearman - Karber formula (Udupe, 1986) as follow:

with the length range is estimated as:

$$
\mathrm{m}=\left(\mathrm{X}_{\mathrm{k}}+\frac{\mathrm{X}}{2}\right)-\left(\mathrm{X} \sum \mathrm{p}_{\mathrm{i}}\right)
$$

$$
\mathrm{CL}=\operatorname{antilog}(\mathrm{m} \pm 1.96 \sqrt{(\operatorname{var}(\mathrm{m})})
$$

Where: $m=$ length size at first gonad maturity; $X_{k}=$ logarithm size at which $100 \%$ of fish are fully mature; $X=$ logarithm of size increment; $p_{i}=\frac{r_{i}}{n_{i}}=$ proportion of mature fish for each size group; $r_{i}=$ frequency of mature gonad on fish length class $-i ; n_{i}=$ the number of fish samples on length class $-i$

\section{Gonadosomatic Index (GSI)} 1997):

The fish gonadosomatic index (GSI) was calculated using the following formula (Effendie,

$$
\mathrm{GSI}=\frac{\mathrm{Bg}}{\mathrm{Bi}} \times 100 \%
$$

Where: $\mathrm{GSI}=$ Gonadosomatic Index (\%); Bg = gonad weight (gram); Bi = fish weight (gram)

\section{Fecundity}

Fecundity was performed on female Oci fish samples, which were in TKG III and TKG IV. The number of eggs was calculated using a combined gravimetric and volumetric method by Effendie (1997) as follow:

$$
F=\frac{G \times V \times X}{Q}
$$

Where: $F=$ fecundity (eggs); $G$ = gonad weight (gram); $V$ = dilution volume $(10 \mathrm{ml}) ; \mathrm{X}=$ number of eggs per $\mathrm{ml}$; $\mathrm{Q}=$ sample eggs weight (gram) 


\section{RESULTS AND DISCUSSION}

Gonad Maturity Stage (GMS) is an essential aspect in the study of fish reproductive biology. GMS is the stage of gonad development before and after spawning. As the gonad's maturity increases, the fish eggs and sperm develop. Gonadal weight of the fish will reach its maximum shortly after the fish will spawn then will decrease rapidly during the spawning process that lasts to completion. Ma'ruf et al. (2019) stated that during the process, most of the metabolic output would be directed towards the development of the gonads. The recording of the gonad maturity stage is needed to know when fish from specific populations spawn. Gonadal fish development varies significantly among species. Likewise, the populations of the same fish species that inhabit waters with diverse conditions and geographical locations might have different GMS.

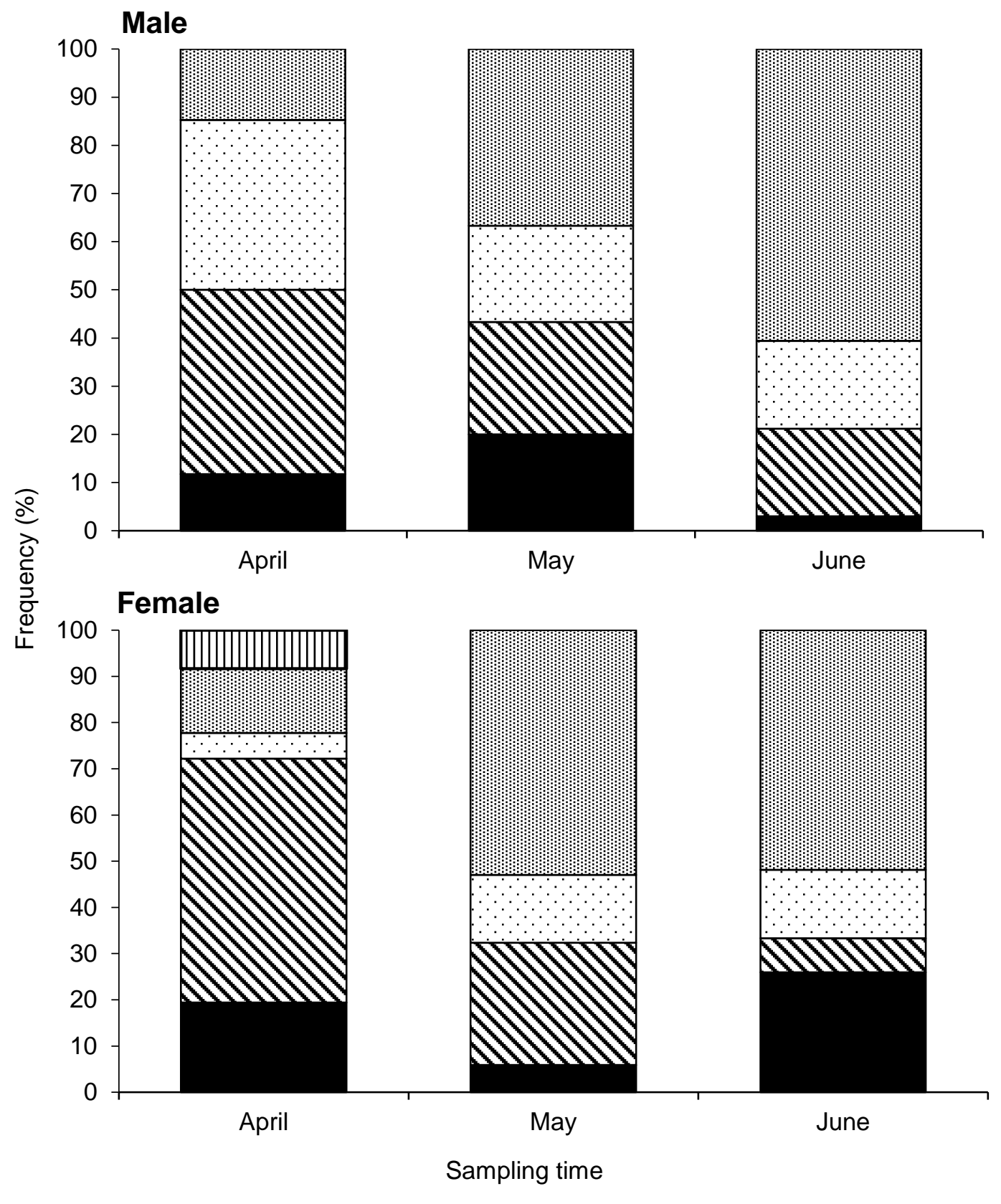

-GMS IV $\triangle G M S$ III 口GMS II 国GMS I هGMS V

Figure 3. Gonad Maturity Stage (GMS) of Oci Selaropides leptolepis in Tomini Bay during April, May, and June 2020 
The results of this study indicate that the percentage of male and female GMS from the three months observation has a similar distribution pattern. In April, it was dominated by fish in GMS III by $53 \%$ (female) and $38 \%$ (male). In May, it was dominated by fish in GMS I by $53 \%$ (female) and $37 \%$ (male). In June, it was dominated by GMS by $52 \%$ (female) and $61 \%$ (male) (Figure 3). Overall, male and female Oci S. leptolepis were mostly in the GMS III and IV in April. This is a signal that April is the Oci spawning season in Tomini Bay. In Sungailiat, around the waters of the Karimata Strait area, Sriyanti et al. (2017) informed that S. leptolepis dominating TKG III and IV were found in April and May. Although a slightly different TKG distribution pattern was shown, this is common for pelagic fish. As cited from Roy et al. (1992), that in some areas, the spawning season of pelagic fish coincides with the upwelling season, but in other areas spawning and upwelling are out of phase.

Male
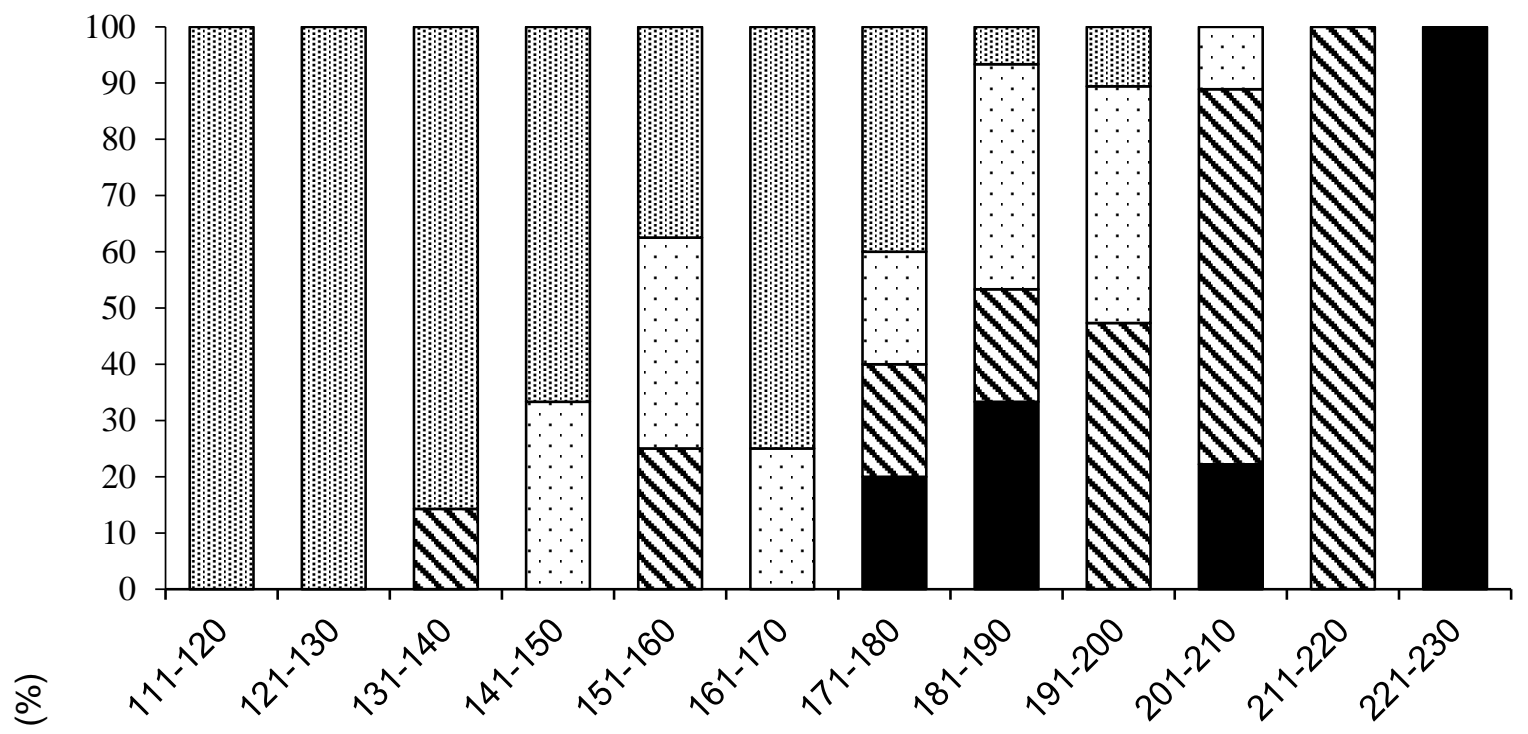

은

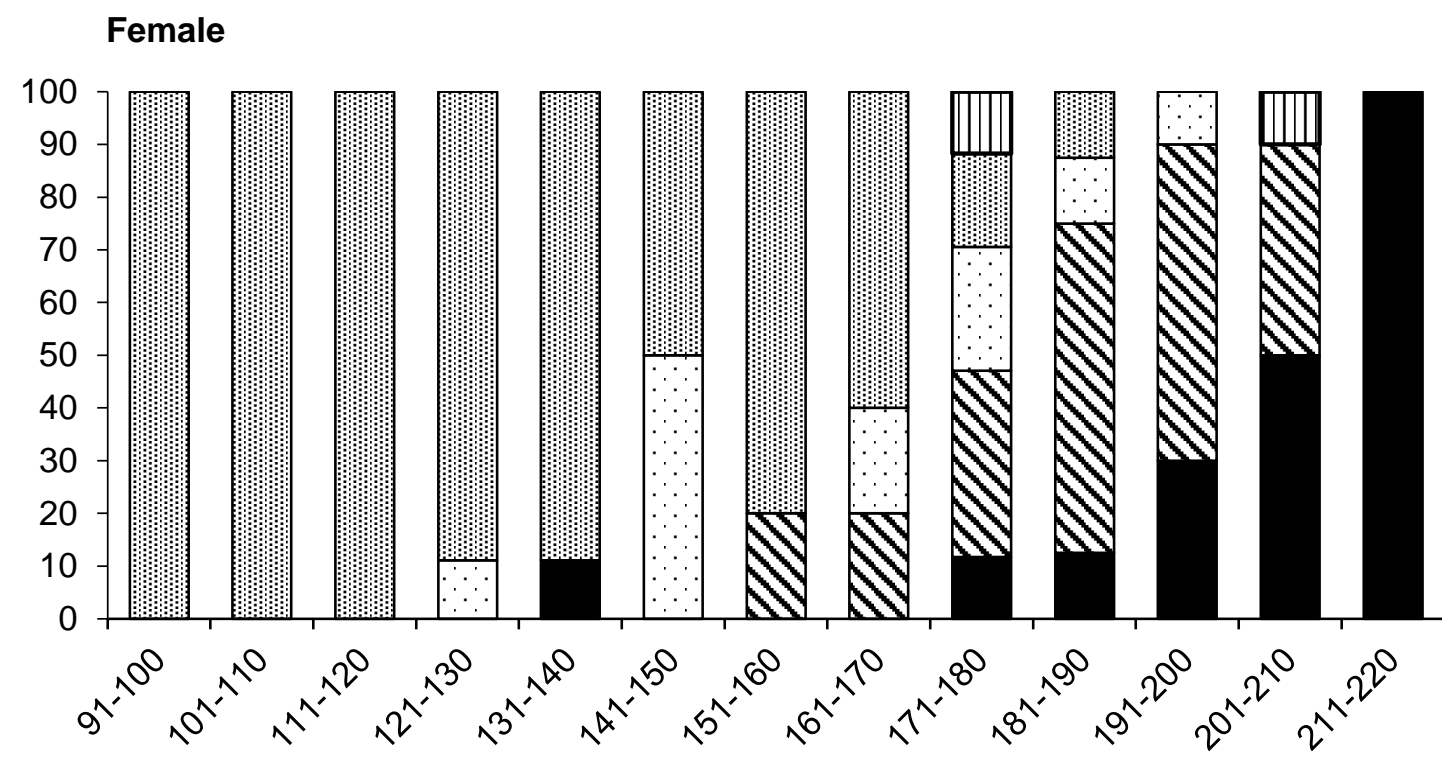

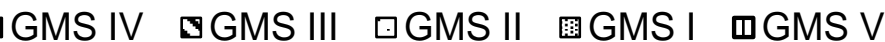

Length class $(\mathrm{mm})$

Figure 4. The proportion of Gonad Maturity Stages (GMS) of Oci Selaropides leptolepis in Tomini Bay based on length body during sampling periods 
Gonadal development is increasingly visible along with the growth of fish body length (Figure 4). Based on the length range, males begin to develop gonads at a size of $131-240 \mathrm{~mm}$, while this occurs in females at 121-130 mm. Both sexes of fish are in full GMS IV at different lengths, where 221-230 $\mathrm{mm}$ for males and 211-220 $\mathrm{mm}$ for females.

\section{Length at first maturity}

The results show that the average size of the first gonad maturity of Oci fish is $173 \mathrm{~mm}$ and $167 \mathrm{~mm}$ for male and female fish, respectively. The size of a mature female Oci is smaller than the male. It indicates that female Oci matures faster than the male. Dissimilar results revealed by Ibrahim et al. (2016) in the Sunda Strait waters that male and female of S. leptolepis first matured gonads at a length of $105.5 \mathrm{~mm}$. Sinaga et al. (2018) reported that the size of the first mature male and female gonads of $S$. leptolepis in Manado Bay was $189 \mathrm{~mm}$ in length. The various size of mature fish from different areas can predict of exploitation level and the existence of the resources in the area as a form of a growth and reproduction strategy. The smaller the fish length of the first time mature relative to the same species found in a particular location, the higher the level of threat faced by fish in the waters.

\section{Gonadosomatic Index}

Gonadosomatic Index (GSI) is a quantitative index that shows a condition of fish sexual maturity. In general, the longer the body, the higher the gonad index value. It shows that a more mature ovary has higher weight and size, including the addition of egg size. In April, the highest average GSI values were found for males and females and then declined in the following two months (Figure 5). This pattern further strengthens the suspicion that the Oci spawning season in Tomini Bay takes place in April.

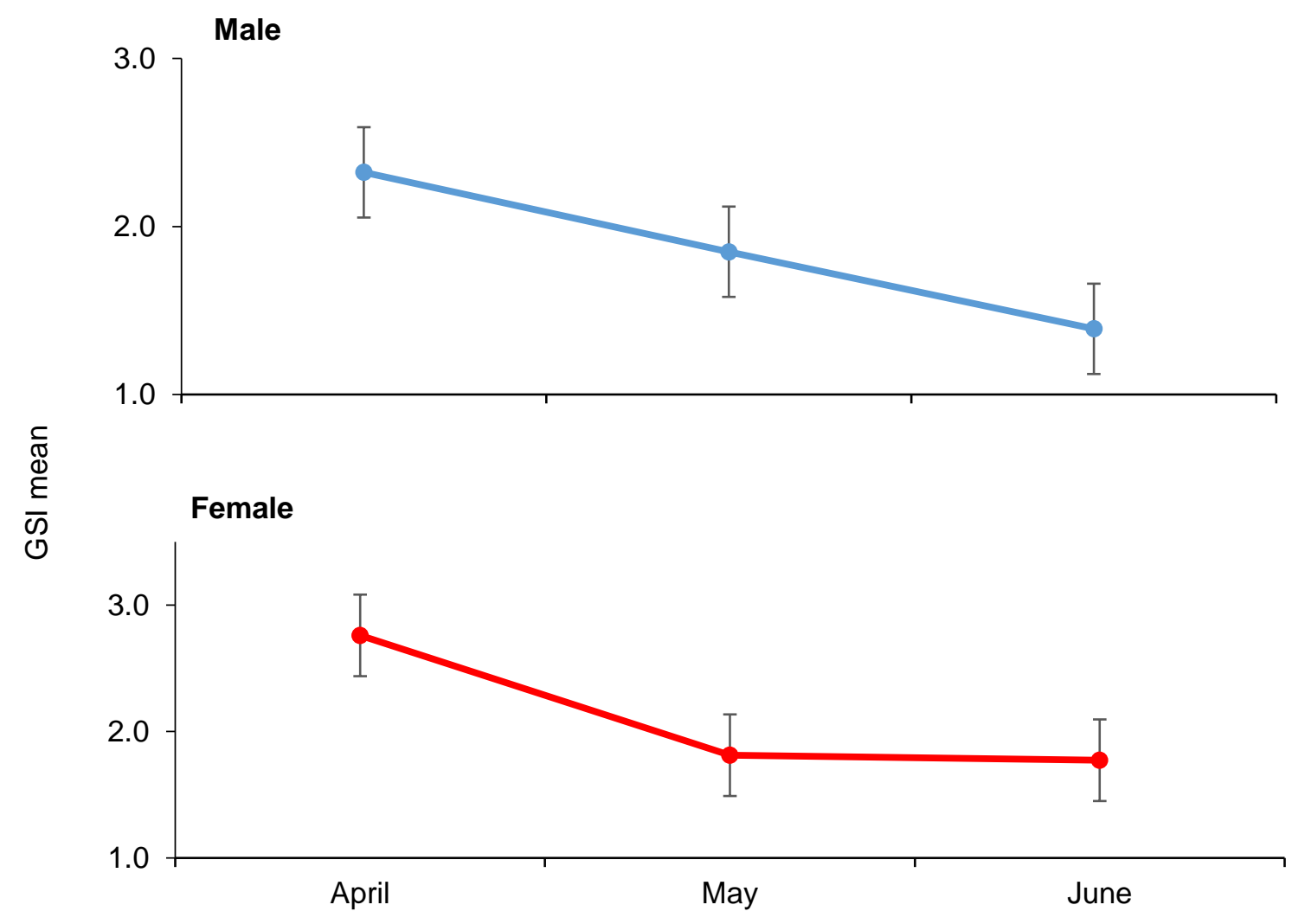

Sampling time

Figure 5. GSI mean of Oci Selaroides leptolepis in Tomini Bay during April, May, and June 2020 
Table 2.. Fecundity of Selaroides leptolepis in Tomini Bay during April, May, and June 2020

\begin{tabular}{|c|c|c|c|c|}
\hline No & Month & Length (mm) & Weight $(\mathrm{g})$ & Fecundity (eggs) \\
\hline 1 & \multirow{25}{*}{ April } & 180 & 74.30 & 7747 \\
\hline 2 & & 180 & 84.92 & 22902 \\
\hline 3 & & 180 & 96.38 & 12574 \\
\hline 4 & & 185 & 106.00 & 13769 \\
\hline 5 & & 190 & 86.20 & 12557 \\
\hline 6 & & 190 & 95.86 & 13106 \\
\hline 7 & & 194 & 91.86 & 14541 \\
\hline 8 & & 195 & 107.90 & 17169 \\
\hline 9 & & 195 & 102.98 & 9005 \\
\hline 10 & & 195 & 97.80 & 16188 \\
\hline 11 & & 195 & 96.38 & 16409 \\
\hline 12 & & 195 & 83.20 & 16956 \\
\hline 13 & & 200 & 115.00 & 17053 \\
\hline 14 & & 200 & 103.00 & 14925 \\
\hline 15 & & 200 & 102.00 & 15703 \\
\hline 16 & & 200 & 101.00 & 13841 \\
\hline 17 & & 200 & 106.86 & 16805 \\
\hline 18 & & 200 & 111.86 & 19261 \\
\hline 19 & & 200 & 105.04 & 20245 \\
\hline 20 & & 200 & 105.58 & 19410 \\
\hline 21 & & 200 & 113.84 & 15901 \\
\hline 22 & & 203 & 90.60 & 15135 \\
\hline 23 & & 205 & 121.00 & 16782 \\
\hline 24 & & 205 & 110.14 & 19507 \\
\hline 25 & & 210 & 109.00 & 12535 \\
\hline & \multirow{10}{*}{ May } & 160 & 45.15 & 21409 \\
\hline 2 & & 163 & 49.48 & 8106 \\
\hline 3 & & 175 & 73.95 & 9211 \\
\hline 4 & & 177 & 62.79 & 12126 \\
\hline 5 & & 179 & 69.35 & 9792 \\
\hline 6 & & 182 & 72.98 & 15460 \\
\hline 7 & & 197 & 97.03 & 19531 \\
\hline 8 & & 199 & 96.94 & 16103 \\
\hline 9 & & 202 & 104.65 & 18540 \\
\hline 10 & & 207 & 105.81 & 27629 \\
\hline 1 & \multirow{9}{*}{ June } & 132 & 14.03 & 25391 \\
\hline 2 & & 164 & 57.34 & 15210 \\
\hline 3 & & 180 & 76.28 & 20746 \\
\hline 4 & & 180 & 74.49 & 19617 \\
\hline 5 & & 185 & 75.89 & 25009 \\
\hline 6 & & 201 & 105.75 & 8837 \\
\hline 7 & & 203 & 119.08 & 24225 \\
\hline 8 & & 205 & 113.17 & 21324 \\
\hline 9 & & 211 & 134.73 & 23077 \\
\hline
\end{tabular}




\section{Fecundity}

Fecundity is the number of eggs in a female fish before it is released when it will spawn. Therefore, the calculation of the number of eggs was only prepared on fish that are in TKG III and IV. In each sampling period, the fecundity in April, May, and June were $15601 \pm 3390,15791 \pm$ 6194 , and $20382 \pm 5364$, respectively. In total, the range of Oci fish fecundity was $7747-27629$ eggs (Table 2). Sinaga et al. (2018) reported that the average fecundity of $S$. leptolepis fish caught in the waters of Manado Bay during April and May 2018 was $11716 \pm 6088$ eggs. Fecundity has a relationship with age, length, or weight of individuals and fish species (Effendie, 1997). Therefore, differences in the number of eggs among the different months and locations are reasonable. Fecundity is also generally associated with egg diameter distribution to predict fish pattern spawning. S. leptolepis is a species that has a partial spawning pattern (lbrahim et al., 2016; Hestiana et al., 2019).

\section{CONCLUSION}

Based on research during April, May, and June 2020, it can be concluded that the Oci Selaroides leptolepis Fish in Tomini Bay first time mature was 173 and $167 \mathrm{~mm}$ at length for male and female correspondingly. The gonadosomatic index ranges between 1,773 and $2,760 \%$, with the highest percentage index occurring in April. The range of fish fecundity is approximate of $11716 \pm 6088$ eggs.

\section{REFERENCES}

Adam, N., Nursinar, S., \& Fachrussyah Z.C. 2020. Parameter Dinamika Populasi Cakalang yang Didaratkan di PPI Tenda. Jurnal Nike, 5(3):78-83.

Anugerah P., Arfiati D., Yuli H., \& Endang. 2019. The Feeding Habit of Yellow Fish (Selaroides leptolepis) in Lekok Waters, East Java. International Journal of Scientific and Technology Research, 8(12):386-387.

Asruddin, A., \& Hasan, M. 2019. Respon Ikan Kembung Terhadap Warna Umpan Pada Alat Tangkap Pancing Ulur Di Teluk Tomini. Jurnal IImu Kelautan Kepulauan, 2(1):84-91.

Asruddin, A., Syariah, N. \& Hasan, M. 2019. Respon Ikan Kembung Terhadap Warna Umpan pada Alat Tangkap Pancing Ulur di Teluk Tomini. Jurnal IImu Kelautan Kepulauan, 2(1):84-91

Baskoro, M. S., Riyanto, M., \& Mawardi, W. 2020. Respons Fisiologi Mata Ikan Selar (Selaroides leptolepis) dan Kembung (Rastreliger brachysoma) terhadap Warna Cahaya Lampu. Jurnal IImu dan Teknologi Kelautan Tropis, 12(1):277-288.

Desrita, Tarigan, A., \& Yusni, E. 2020. Fecundity and Size the First Maturity of the Gonad of Yellowstripe Scad (Selaroides leptolepis) at Belawan Aquatic, North Sumatera. IOP Conference Series: Earth and Environmental Science, 454(1):012136.

Effendie, M. I. 1997. Metoda Biologi Perikanan. Fakultas Perikanan IPB. Bogor. Yayasan Agromedia. Bogor.112p

Fawzya, Y. N., Nursatya, S. M., Susilowati, R., \& Chasanah, E. 2020. Characteristics of Fish Protein Hydrolysate from Yellowstripe Scad (Selaroides leptolepis) Produced by a Local Microbial Protease. in E3S Web of Conferences, 147: 03017. EDP Sciences:1-10.

Fuad, F., Baskoro, M. S., Riyanto, M., \& Mawardi, W. 2020. Physiological Response of the Eye Yellow-striped Scad (Selaroides leptolepis) and Short Mackerel (Rastreliger brachysoma) to the Color of Light. Jurnal Ilmu dan Teknologi Kelautan Tropis, 12(1):277-288.

Hatta, M., \& Mulyani, S. 2019. Kebiasaan Makan Ikan dan Trofik Level Sepanjang Perairan Pantai Kabupaten Barru. Jurnal Dedikasi, 21(1):77-79.

Hestiana, Yasidi F. \& Mustafa A. 2019. Biologi Reproduksi Ikan Selar Kuning (Selaroides leptolepis) di Perairan Wolo Kabupaten Kolaka. Jurnal Manajemen Sumber Daya Perairan, 4(1):23-30

Hussin, S. N., Azlan, A., Khoo, H. E., Kadir, N. A. A. A., \& Razman, M. R. 2019. Comparison of Fat Composition and Chemical Properties of Fat Extracts between Fish Fillets of Selected Warmwater and Cold-water Fish. Bioscience Journal, 35(6):1968-1978. 
Ibrahim, P. S., Setyobudiandi I., Sulistiono. 2016. Biologi reproduksi ikan selar kuning (Selaroides leptolepis Cuvier, 1833) di Perairan Selat Sunda. Prosiding: Seminar Nasional Ikan ke-9. Masyarakat Iktiologi Indonesia.

Imbir, Y. K., Onibala, H., \& Reo, A. R. 2019. Analisa Kadar Air dan Uji Organoleptik pada Ikan Selar (Selaroides leptolepis) dan Ikan Cakalang (Katsuwonus pelamis L). Jurnal Media Teknologi Hasil Perikanan, 2(2):27-31.

Jaafar, M. T. N., Taylor, M. I., Mohd Nor, S. A., Bruyn, M. D., \& Carvalho, G. R. 2020. Comparative Genetic Stock Structure in Three Species of Commercially Exploited Indo-Malay Carangidae (Teleosteii, Perciformes). Journal of Fish Biology, 96(2):337-349.

Khatami, A. M., Yonvitner, Y., \& Setyobudiandi, I. 2019. Biological Characteristic and Exploitation Rate of Small Pelagic Fishes in North Java Sea. Jurnal IImu dan Teknologi Kelautan Tropis, 11(3):637-651.

Ma'ruf, M. M., Syarif, A. F., Bidayan, E. 2019. Reproductive Performance of Climbing Perch (Anabas testudineus) Females Suplemented Feed of Golden Snail (Pomacea canaliculata) Flour as Raw Materials. Jurnal Perikanan, 9(1):30-49.

Madjowa, V., Olii, A. H., \& Baruadi, A. S. R. 2020. Gorontalo Fishermen Knowledge Studies Related to Astronomy and the Movement of Fish in Tomini Bay. Asian Journal of Fisheries and Aquatic Research, 6(2):41-49.

Mardlijah, S., \& Rahmat, E. 2016. Penangkapan Juvenil Ikan Madidihang (Thunnus albacares Bonnatere 1788) di Perairan Teluk Tomini. BAWAL Widya Riset Perikanan Tangkap, 4(3): 169-176.

Nento, W. R., Nurhayati, T., \& Suwandi, R. 2014. Perubahan Mutu Daging Terang Ikan Tuna Yellowfin di Perairan Teluk Tomini Propinsi Gorontalo. Jurnal Pengolahan Hasil Perikanan Indonesia, 17(3):225-232.

Rahmat, E., \& Witdiarso, B. 2017. Operasional alat tangkap pukat cincin mini (mini purse seine) di Teluk Tomini oleh nelayan di gorontalo. Buletin Teknik Litkayasa Sumber Daya dan Penangkapan, 15(1):31-34.

Roy, C., Cury, P., \& Kifani, S. 1992. Pelagic fish recruitment success and reproductive strategy in upwelling areas: environmental compromises. South African Journal of Marine Science, 12(1): 135-146.

Sahara, S., Djufri, D., Safrida, S., Supriatno, S., \& Khairil, K. 2020. The Utilization of Papaya Seed Powder (Carica papaya L.) Against the Selar Fish Protein Levels (Selaroides leptolepis). Jurnal Ilmiah Mahasiswa Pendidikan Biologi, 5(1):145-150.

Sinaga, F., Tilaar, F. F., \& Bataragoa, N. E. 2018. Characteristics of Reproduction of Yellowstripe Scad Selaroides leptolepis (Cuvier, 1833) In Manado Bay Waters. Jurnal IImiah Platax, 6(2): 46-57

Sriyanti, S., Adi, W., \& Utami, E. 2017. Hubungan Kebiasaan Makan dengan Kematangan Gonad Ikan Selar Kuning (Selaroides leptolepis) yang didaratkan di Pelabuhan Perikanan Nusantara Sungailiat. Akuatik: Jurnal Sumberdaya Perairan, 12(2):9-16.

Suwarso, S., Sadhotomo, B., \& Wudianto, W. 2017. Perkembangan Perikanan Pelagis Kecil di Teluk Tomini: Suatu Pendekatan ke Arah Manajemen yang Bertanggung Jawab. BAWAL Widya Riset Perikanan Tangkap, 1(6):233-244.

Wagiyo, K., Priatna, A., \& Herlisman, H. 2019. Kelimpahan, Komposisi dan Sebaran Larva Ikan di Laut Seram, Laut Maluku dan Teluk Tomini (WPP 715). Bawal, 11(1):1-17. 